\title{
School Libraries in the English Education of Japan: From the Perspectives of Practitioners
}

\author{
Masato, FUJITA \\ Saitama Prefectural Iruma Koyo High School / Tokyo Gakugei University \\ 1-1-1, Koyodai, Iruma-shi, Saitama / 4-1-1, Nukuikitamachi, Koganei-shi, Tokyo \\ Japan, \\ b072918x@st.u-gakugei.ac.jp \\ Minoru, MAEDA \\ Tokyo Gakugei University \\ 4-1-1, Nukuikitamachi, Koganei-shi, Tokyo \\ Japan, \\ mmaeda@u-gakugei.ac.jp
}

\begin{abstract}
School Libraries as a Foreign Language Learning Environment
In Japan, English has been taught as a foreign language. For surviving in the quickly changing 21 st century, students have to learn English more autonomously, gathering authentic input by themselves. Though school libraries can be a solution to such problems, appeal to English educators is not sufficient and such educators do not fully understand the possibilities offered by school libraries. The voices of practitioners of English education who utilise school libraries were needed in this respect. This study shared the perspectives of practitioners, using interviews in order to reveal the potential uses of school libraries. The study concluded with the possibility that school libraries can form an English learning environment in which students' autonomy is cultivated and authentic input is provided.
\end{abstract}

Keywords: English as a foreign language, autonomy, practitioners 


\section{Introduction}

In Japan, English is mainly taught as a foreign language. Especially in high schools, English is taught using the grammar translation method (GTM), in which students translate English into Japanese and teachers add grammatical remarks. Nowadays, however, such a passive method is criticised as ineffective for surviving quick changes in the 21st century (see Section 3.1 for more detailed discussion). English educators have begun to seek a way of cultivating students' autonomy. In addition, the language environment in Japan, as well as in other Asian countries, is termed English as a foreign language (EFL). In an EFL environment, there is no need to use English in daily life, while there is great need in English as a second language (ESL) environment. Learners in an EFL environment have to accumulate more authentic input than textbooks provided in English classrooms.

School libraries may be the solution to the problems raised above, cultivating students' autonomy and providing resources of authentic input. However, English educators are not aware of such potential uses of school libraries because of the lack of practitioners' voices (we will discuss this in more detail in Section 3.2).

There is a need to reveal the possibilities of school libraries and share them with English educators. To appeal to such educators, the perspectives of practitioners who use school libraries in English education can be most important. In this study, the authors gathered voices of practitioners in order to clarify school libraries' potential uses for solving problems in English education.

\section{Aim}

The aim of this study is to discover the potential uses of school libraries for practitioners in English education. In this research, practitioners include not only English teachers but also school librarians and librarian-teachers. In addition, students' perspectives are taken into consideration.

\section{Background}

\subsection{Roles of School Libraries in Japan}

Japanese society has been changing rapidly, and the skills needed in this society are also changing. According to the National Institute for Educational Policy Research (2013), in this

globalised society, worldwide problems such as economic problems and exhaustion of natural resources impact on individuals' lives. Thus, not only some experts but anyone who shares in the problem must contribute to finding an answer, even if it is insufficient, and carrying it out. To solve the complex problems we face, this report suggested that competencies required for the 21st century mainly focus on thinking skills, which are founded on the basic skills of language literacy, mathematical literacy and information literacy. Based on these basic skills, thinking 
skills such as problem solving, logical/critical thinking and metacognitive monitoring/control are established. After acquiring thinking skills, these skills are supposed to be applied in practice. The 21st century competencies consist of basic skills, thinking skills and skills of practice. Again, the most important skills out of the three are thinking skills.

Education in Japan is changing correspondingly. Inai (2014) confirmed the importance of learning by exploring, which is emphasised in the Course of Study to cultivate students' learning skills. He also stated that attitude and skills for problem finding/solving with other students are important, in addition to scholastic achievement in a narrow sense. Education in school libraries should contribute to bringing up a person who has skills of problem solving, communication and thinking in response to these social needs.

The Conference of Supporters of Children Reading (2009, pp. 3-4) described the roles and functions of school libraries in Japan as follows:

(1) A center of reading

School libraries are places where students read freely and should be used for reading education. School libraries cultivate students' creativity, as well as generosity, and foster a positive attitude toward studying.

(2) A center of learning and information

School libraries support students' spontaneous and autonomous study. School libraries cultivate students' skills of gathering, choosing, and utilizing information and contribute to school curricula.

(3) A function of supporting teachers

Utilizing school libraries is stipulated in the general provisions of the Course of Study. Every teacher is required to utilize libraries through teaching each subject. Every teacher should acquire skills to make the best use of functions of school libraries to improve their instruction.

Although (1) and (2) are relevant in this study, (3) (function and role) also has an important implication. Every teacher in Japan should be able to utilise school libraries to improve students' thinking skills. English, as one of the subjects taught in schools, is not an exception. The next section will discuss English education in school libraries.

\subsection{English Education in School Libraries}

The discussion of English education in school libraries has been focussed on the materials and facilities that English education has required. The meta-research of Iba (2006) described three 
problems of English education in school libraries: budget, contents of materials and how to utilise school libraries.

Though limited, there are several studies (Yagi, 2005; Yagi et al., 2006; Yagi, 2008) regarding English education in school libraries. Yagi (2005) discussed school libraries as a base of language education (Japanese and English) and pointed out the insufficiency of attention paid by EFL educators to English education in school libraries. He complained that there were few practitioners' reports that involve utilisation of school libraries at academic conferences. According to his other works, Yagi et al. (2006) and Yagi (2008), process models of English education and library user education have a similarity (this similarity will be examined in Section 5.3); in addition, cooperation of school libraries and English education was found to be desired by teachers. However, there are not so many teachers' reports.

More recently, school libraries in Japan have paid greater attention to English education as extensive reading practice has become popular. Several reports describe extensive reading using school libraries (e.g., Imamura, 2015, Yonezawa, 2012; Yonezawa, 2014). Yonezawa claimed that books for extensive reading should be placed in school libraries.

School libraries certainly play a role in English education. Most studies mentioned above, however, did not focus on practitioners' perspectives on English education in school libraries. More importantly, there was little attention paid to the thinking skills cultivated in school libraries. School libraries in Japan need to appeal to English educators to a greater extent. For a deeper understanding of what school libraries can do for English education in Japan, more voices from practitioners are needed. This study therefore focuses on the perspectives of practitioners who use school libraries, paying attention to the thinking skills that are central for the 21st century.

\section{Method}

Unstructured interviews concerning the practice of English education in school libraries were conducted. Six English teachers, one librarian-teacher and two school librarians in six schools provided their experience as practitioners. Their interviews were recorded and transcribed, and the scripts were sent to them by email for confirmation. The author failed to record one of the interviews, and the interview notes were sent and confirmed instead. Classroom observation was allowed to be carried out in two schools. This provided further information on the practice of the interviewees.

Case studies on English education in school libraries were included as a data resource as well. Supporting evidence was also provided from the principal author's own case studies as an English teacher. 


\section{Results and Discussion}

Four key themes were derived from the interviews. They are interpretations of school libraries, uniqueness of English education in school libraries, the mutually complemental nature of English education and school libraries, and changes of both English education and school libraries. This chapter consists of descriptions of these themes. All the interviews and most of the case studies mentioned above were conducted in Japanese and translated into English for the following discussion by the principal author.

\subsection{Interpretations of School Libraries}

To investigate what sort of potential school libraries have for practitioners, it is essential to understand what school libraries mean to practitioners. This section describes practitioners' interpretations of school libraries.

Interpretations differ from one practitioner to another and indicate the flexibility of school libraries. Practitioners, as other studies such as Shiomi (2006) and Watanabe (2009) point out, notice that school libraries are used in more than one way. For example, Shiomi (2006) claims that school libraries are places not only for reading books. They are now widely considered as resource centres that are hubs for community and lifelong education. The common theme extracted from these interpretations seems to be, 'A library is a community centre for learning', where learners cooperate with one other, use the wealth of resources in the library and explore their own topics. Through experiencing such a community, students are quite likely to communicate and think more creatively.

The practitioners also mentioned the function of libraries as reading centres as well as learning and information centres, which are mentioned in Chapter 3. The six schools contained both functions. For example, extensive reading can be considered to utilise a function of a reading centre, and a research project in a library can be explained as making use of a function as a learning and information centre. These two different functions had an impact on the practitioners' interpretations of libraries. Two of the interviewees who are teachers had used the libraries with both functions, but, first, their comments about the function as a reading centre are discussed.

Their comments seemed to explain an advantage of extensive reading. That is, students spontaneously read what they want to read, keeping their pace and interest, which can motivate them for further reading. This can be interpreted as the function of reading centres for a library: Mitsuno and Fukuda (2012) reported that children in their elementary school came to a library to read Japanese versions of the books that were read in a class involving foreign 
language activities, finding differences in the two versions and getting into the worlds of the books more deeply. In school libraries as reading centres, students are supposed to read voluntarily. Such a norm corresponds with the principle of extensive reading and makes the extensive reading more effective. Since the students are supposed to choose their own books, they are required to monitor and control their learning.

As for the function as learning and information centres, which are also considered to help students' autonomous learning, the interpretation of the library is different for practitioners. Though the two teachers do not oppose the idea that school libraries can facilitate autonomous learning, their focus is mainly on the media available in school libraries. Their interpretation of school libraries as learning and information centres can be described as constituting 'a multimedia centre'.

Based on the interpretations above, the next three sections describe English education in school libraries in Japan.

\subsection{Uniqueness of English Education in School Libraries}

Though competence that can be achieved in school libraries goes beyond boundaries among subjects, English teachers have unique reasons to utilise school libraries. One of them is to improve learners' skills in reading spontaneously. Indeed, libraries are the optimal place for students' reading in school.

Some of the interviewees agreed that a school library is essential for extensive reading, as it is arduous to manage books. One interviewee who is a school librarian added that borrowing books in a school library, no matter whether they are written in English or Japanese, is quite natural for students. Kishida (2006) conducted interviews mainly with high schools and colleges of technology. She insisted that a library 'is an external factor which affects the ER [Extensive Reading] program to a great extent' (p. 59). Her interviewees admitted that help from school libraries and school librarians is quite important. This help includes supervising the books, providing space for reading and purchasing books.

If practitioners would like to help learners' autonomous reading, as we have seen in the previous section, establishing the optimal environment for cultivating autonomy is especially beneficial. Since one of its central roles is to provide a place for reading, a library is a better location than a classroom in this respect. Students can concentrate, communicate with one other through books and consult books in Japanese if necessary. In fact, one of the interviewees' cases shows that the students benefited from reading the same book in both English and Japanese. This comparison leads to deeper thinking, associating the knowledge 
obtained in their first and second languages. In addition, English teachers can save time to supervise books.

In order to enable students to read, Watanabe (2009) claimed that it is not sufficient to provide books. There should be teachers who hand books to students; moreover, this should be linked to teaching in classes. This statement would also be applied to English education. Kasahara (2005) argued that reading activities should be planned yearly by a school library. Although Japanese education seems to be the primary subject to take part in such a plan, English education can join in language education as well. Language education puts more emphasis on reading than other subjects as one of the four skills. English teachers should hand out books during English classes if they hope for their students to be able to read. In a school library, there would be a collection of books optimised for teachers to choose for their students. There could also be school librarians and librarian-teachers who support teachers and students in choosing the right books. A school library serves as the best environment not only for students to read but for teachers to hand their students books. Such an environment is a unique reason for English teachers to utilise school libraries. There would be no doubt of the importance of reading in teaching English and establishing an optimal environment for reading.

A school library as an environment for reading is not the only unique part of English education utilising a school library. According to Endo (2014), while an English teacher should provide an actual language-use situation to introduce a concrete image of the contents of study, there are not so many things that one English teacher alone can prepare learning materials effectively. Endo points out that exploring resources in school libraries can help enable students to achieve the viewpoints espoused by the Ministry of Education, Culture, Sports, Science and Technology (MEXT, 2010). MEXT states that teaching materials in English education should be useful in the following ways:

A. enhancing understanding of various ways of viewing and thinking, fostering an ability to make impartial judgments and cultivating a rich sensibility. B. deepening understanding of ways of life and cultures of foreign countries and Japan, raising interest in language and culture and developing respectful attitudes toward these.

C. deepening international understanding from a broad perspective, heightening students' awareness of being Japanese citizens living in a global community and cultivating a spirit of international cooperation. (p. 8)

Interviewees in this study are also aware of the effectiveness of the teaching materials that school libraries offer. Practitioners are aware that, in English education, teaching materials apart from textbooks play considerably important roles. Such materials can offer actual 
situations of language use, advanced communication activities and natural input, which teachers in other subjects might not need. Especially in an EFL environment, English teachers have to seek out authentic resources other than textbooks. A school library can act as a resource centre, utilising multimedia. Due to the resources that school libraries supply, students will be able to utilise their language literacy and analyse information effectively.

\subsection{Mutually Complemental Nature of English Education and School Libraries}

Yagi (2008) analysed the process models of English education and library user education. He considered the metacognitive model as a process model of English education and the information problem-solving model as a process model of library user education. The metacognitive model was related to problem solving and self-education, while the information problem-solving model was related to problem solving and information utilisation. By integrating these two models, learning from one model can transfer to learning from another. Thus, Yagi concluded that the relationship between them is mutually beneficial. Such a complementary nature is true from the perspectives of practitioners as well. English education in school libraries lets learners apply basic English skills that they have learned in classrooms to an authentic situation in which they can actually use these skills. For example, students who join an extensive reading course in school libraries make use of their vocabulary and grammar knowledge to read authentic books. One of the interviewees in this study also suggested that classroom-English improves learners' basic English skills, while library-English encourages them to advance the basics they have already gained in the classroom.

In addition, library-English is found to have a positive impact on classroom-English. In one interviewee's case, students were told not to plagiarise. This is library-English in the sense of information utilisation. To avoid plagiarism, students payed more attention to the vocabulary and structures they used, and they improved their skills of expression, which constituted one of the skills taught in classrooms. In other words, information utilising skills acquired in a school library (see Section 3.1) transferred to learning English expressions in the classroom.

In the principal author's own cases of extensive reading in a school library, the students were asked to answer a questionnaire after their classes. The author consequently found that 9 out of 28 students reported that they had gained inference ability, and another 9 students replied that they had become to be able to read books faster. These answers show that the students had made use of the ability they had gained in the classroom. Beyond that, 15 students responded that they still had difficulty in learning vocabulary and noticed that they needed to improve their basic skills. By learning in a library, learners are more likely to find that the English they are taught in a classroom is necessary for further learning, thereby raising metalinguistic awareness. Basic skills students gain in classrooms and utilisation of these skills 
exist in neither a trade-off relationship nor merely a basic-and-advance relationship. They are complementing each other, as well as improving students' metalinguistic competence.

Besides English skills, other new aspects can be found in school libraries. One interviewee referred to engaging in extensive listening while undertaking extensive reading. School libraries collect learning materials other than books, including CDs and DVDs, with students in the interviewee's school being able to borrow CDs, CD players and headsets. In spite of this unique context, it is important to recognise that there are various kinds of learning styles and that school libraries can respond to a variety of needs.

Another interviewee also pointed out that there are some students who cannot keep up with the 'skill-training' nature of English education but are saved in school libraries. She argued that students who are weak in speaking in front of others but fond of reading can improve their overall English skills by extensive reading.

Their issues are similar in the sense of supporting learners' diversity. English language teaching has a 'skill-training' nature. Some learners inevitably fail to acquire some skills if training is the only method teachers provide. School libraries can supplement English language teaching by providing another approach to learning English. If learners are taught using more than one approach, they will be more conscious about how they can control their learning. In other words, their metacognition about learning will become more sophisticated by noticing their various learning styles.

\subsection{Changes in Both English Education and School Libraries}

School librarians and librarian-teachers, who could act as a medium between libraries and users, bring some positive changes to English education by using their specialist knowledge.

We have seen in Section 5.2 that school libraries can serve as resource centres that provide materials other than textbooks, and that this can be helpful for EFL learning. Teachers and students, however, are not experts in finding the appropriate information for learning, and they therefore need help to search the multimedia of school libraries. School librarians and librarian-teachers are experts of library science; hence, their reference service is necessary for English teachers to assemble suitable materials to use in their classes. The service is also helpful for students in finding the information that they need. To put it more concretely, school librarians in the interviewees' stories collected information from their own libraries, public libraries and other school libraries that formed a network. A variety of contents are found in EFL classes, and exploring several libraries is essential for research projects related to EFL. With experts' support, interviewees and their students carried out their projects efficiently. 
Students also need such experts' help so as to gain enough information literacy in order to carry out their research. Otherwise, they cannot obtain appropriate information. As mentioned in Section 3.1, information literacy is one of the basic skills that make up the foundation of thinking skills, as well as language literacy. School librarians and librarian-teachers are supposed to improve students' information literacy through services such as a reference service. Watanabe (2009) proposed that information literacy would be developed through seeking, organising, examining and communicating with information. She also pointed out that one of the roles of librarian teachers should be to support this process, aiming at the systematic development of information literacy through learning in a school curriculum. According to the Ministry of Public Management, Home Affairs, Posts and Telecommunications (n.d.), Article 6, in which school librarians were introduced officially for the first time, was added to the School Library Act in Japan in 2015. School librarians will join librarian-teachers more than ever and play a more active role in cultivating information literacy. Based on information literacy, English education in school libraries is established.

One of the interviewees mentioned another facet of multimedia in a school library. Some school libraries have facilities such as a screen, a projector, an electric blackboard and so on. For example, libraries in her school include computers, printers, whiteboards, audiovisual equipment, projectors and screens to be used in a class. School librarians and librarian-teachers can manage these facilities so as to support English education that emphasises sharing information through, for example, presentation, and can thus contribute to establishing a learning community. The practitioners' interpretation discussed in Section 5.1 specified: 'A library is a community centre for learning.' To build this community, such devices are important. Staff in school libraries can create a community by establishing a learning environment, and students will consequently share their input and feedback.

We have hitherto concentrated on school librarians and librarian-teachers in libraries as learning and information centres. Let us now shift the emphasis back to reading centres.

In the case of one interviewee, the department of English featured graded readers at first. The interviewee's librarian-teacher suggested some series to enrich the collection and bought them as library books. A large and rich collection of books is needed for extensive reading, but it is hard for a teacher to collect them by himself or herself (Kishida, 2006). School librarians and librarian-teachers, as professional collectors of books, can offer solutions to the problem.

Two of the interviewees raised the point that school librarians and librarian-teachers can offer a medium as 'non-evaluators' between teachers and students. School librarians and librarian-teachers do not rate students by giving them tests, and they thus educate students as readers. Indeed, some students can be motivated by being treated as readers. Another 
interviewee who is a librarian-teacher observed students' reading and chose the appropriate books to read. She helped students to choose books containing the appropriate number of words, as shown above, and she also suggested some books based on students' preferences in class when the author observed her in the library. This coaching is called reading education, which librarian-teachers and school librarians offer as one of their services. Daily observation as library staff can help them guide learners to read appropriate books. The students' reading skills, and skills for monitoring and controlling their learning, can be improved by this guidance.

Now that we have discussed the positive effects that school librarians and librarian-teachers offer for English education, we will be able to discuss the effects of English teachers. English teachers also introduce several reforms to school libraries by making the best use of these facilities. One of the reforms involves enriching the collections featured in school libraries. In the case of Hoshi (2012), English books in her school libraries were bought mostly according to English teachers' demands. In her school library, English teachers categorise all English books into levels of readability. English books are difficult to choose; even for experts of library science. English teachers' cooperation can therefore lead to a better collection and develop a better environment for EFL learning.

One reform that English teachers introduce is the professional development of school librarians and librarian-teachers. Yonezawa (2012) reported that, as a school librarian, she tried extensive reading by herself and obtained a perspective as a learner. By the experience of extensive reading, she has widened her understanding and knowledge of books for extensive reading.

The books that English teachers need may be unique. School librarians and librarian-teachers can learn from the requests of English teachers and improve their service by accumulating an understanding of the materials needed for education. English books might be the most unique request. Yagi (2005) mentioned that Japanese education has been discussed primarily in the context of school library user education. This shows the possibility that materials in school libraries are mainly related to Japanese education and that staff in school libraries have not developed skills in choosing English books. Watanabe (2009) said that staff members in school libraries usually use booklists to choose what books to buy. The booklists she showed as examples mainly contained Japanese books. It is unlikely that school librarians and librarian-teachers buy English books without English teachers' request or without observation of extensive reading in a school library. English teachers are able to choose English books that are suitable for the students' proficiency through involvement in English classes. For instance, they can request picture books in English even for high school students, knowing that picture books are easy enough for students to enjoy reading by themselves. Meanwhile, English teachers can provide students with comprehensible input using such relatively easy books. 
School librarians and librarian-teachers can thus understand how to choose and provide proper English books for their students through English teachers' involvement.

\section{Conclusion}

This study explored the potential use of school libraries for practitioners in English education. It was found that the potential use of such libraries is as an educational environment in which students cultivate their autonomy, monitor and control their learning and gain and share more authentic input.

The cooperation between English education and school libraries was found to be beneficial to school libraries as well. School libraries can improve their quality as a learning environment by involving English education. Further research is needed, however, to obtain a deeper understanding of the relationship between English education and school libraries.

\section{References}

Kishida, A. (2006). A Qualitative Approach to Extensive Reading Research: Extensive Reading as Described by High School Teachers. Unpublished master's thesis. Tokyo: Tokyo Gakugei University.

稲井達也(2014).「はじめに」稲井達也（編著）『授業で活用する学校図書館 中学校・探究 的な学習を目ざす実践事例』全国学校図書館協議会. 6-7.

伊庭日出樹(2006).「英語教育のための学校図書館」『Kobe English Language Teaching』21， 3-19.

今村一博(2015).「自由記述式回答用紙を用いた英語多読の研究」『第 41 回全国英語教育学 会熊本研究大会発表予稿集』214-215.

遠藤大輔(2014).「外国語 (英語) 科」稲井達也（編著）『授業で活用する学校図書館 中学 校・探究的な学習を目ざす実践事例』全国学校図書館協議会. 119-124.

笠原良郎(2005). 『読書の楽しさを伝えよう 知と心を育てる読書の教育』ポプラ社.

国立教育政策研究所(2013).『教育課程の編成に関する基礎的研究報告書 5 社会の変化に対 応する資質や能力を育成する教育課程編成の基本原理[改訂版]』 Retrieved October 29, 2015, from http://www.nier.go.jp/05_kenkyu_seika/pdf_seika/h25/2_10_all.pdf 
子どもの読書サポーターズ会議(2009). 「これからの学校図書館の活用の在り方等について

（報告）」Retrieved November 29, 2015, from http://www.mext.go.jp/

a_menu/shotou/dokusho/meeting/_icsFiles/afieldfile/2009/05/08/1236373_1.pdf

塩見昇(2006).『教育を変える学校図書館』風間書房.

総務省(n.d.).『法令データ提供システム』Retrieved February 20, 2016, from http://law.e-gov.go.jp/

中村国男(1984).「学校図書館と教科が結びつくための条件——共同研究から——」『学校図 書館』405, 41-44

星佐都子(2012).「英語教育に対応した資料収集」『学校図書館』739, 34-35.

光野雪子·福田裕美(2012).「外国語を身近にさせる学校図書館活動」『学校図書館』739, 18-20.

文部科学省(2010).『中学校学習指導要領英訳版（仮訳）』Retrieved February 5, 2016, from http://www.mext.go.jp/a_menu/shotou/ne w-cs/youryou/eiyaku/1298356.htm

八木慶太郎(2005).「言語教育の拠点としての学校図書館」『図書館情報学研究』3, 33-42.

八木慶太郎(2008).「英語科における学校図書館の活用に資するモデルの比較検討」『言語文 化教育研究』3, 4-17.

八木慶太郎 - 土屋武久 - 小西正恵 · 戸田光昭(2006). 「高等学校の外国語教育における学校図 書館の活用」『Language Education and Technology』43, 161-176.

米澤久美子(2012).「英語多読と学校図書館」『学校図書館』739, 31-33.

米澤久美子(2014).「学校図書館の多読環境づくり」酒井邦秀・西澤一（編著）『図書館多読 への招待』日本図書館協会. 51-63.

渡辺暢惠(2009). 『実践できる司書教諭を養成するための学校図書館入門』ミネルヴァ書房.

\section{Biographical note}

Masato FUJITA has worked as an English teacher at Saitama Prefectural Iruma Koyo High School in Japan since 2011. He is now a graduate student of Tokyo Gakugei University, majoring in English education since 2015. His main research topic is school libraries in English education. 
Minoru MAEDA has worked as an Associate Professor at Tokyo Gakugei University in Japan since 2004. His main research topic is school libraries. 